\title{
EXPERIENCE WITH BRITISH LATEX SUSPENSION FOR AGGLUTINATION TESTS IN RHEUMATOID ARTHRITIS
}

\author{
BY \\ HARRY COKE \\ Research Department, Charterhouse Rheumatism Clinic, London, W.I
}

Since the initial utilization of polystyrene particles by Plotz and Singer (1956) as a macroscopic indicator basis replacing sheep erythrocytes in the methods originated by Waaler (1940) and Rose, Ragan, Pearce, and Lipman (1948) for the detection of the enhancement of agglutination by a macroglobulin in sera of rheumatoid arthritic cases, many variations in practical techniques have been published. Burby and Behr (1958) recorded a method employing Bovine Cohn Fraction II gammaglobulins as the sensitizing agent. Shortly after this, a British-produced polystyrene (Latex) particle suspension became available (Coke, 1958), and a comparison of the sensitivity of this method with that of the standard Rose-Waaler or sheep cell agglutination test (S.C.A.T.) would seem to be of interest.

Ziff (1957) demonstrated that an element of normal serum protein had a capacity to inhibit agglutination, which was lost or blocked in rheumatoid arthritic serum. He claimed that his method was much more accurate so that 98 per cent. of rheumatoid patients gave positive results, but the technique involved was difficult and time consuming.

The method of Burby and Behr, used in conjunction with the original British polystyrene suspension, was also found to depend on the inhibitory capacity of normal sera and the failure of inhibitory capacity in rheumatoid arthritic sera. Modifications of the British suspension have since been made, and these require the changes in technical procedure described under "Methods".

Any numerical assessment of specific serological tests of the clinical condition in rheumatoid arthritis must rely upon the physician's definition or interpretation of the clinical condition. Until a factual aetiology for this disease process is established, the unknown variations of clinical computation must play a part in the relative value of figures derived from any series of such tests. The clinical estimation becomes more variable in the mild, early, and doubtful ambulant case than in the severe, active, hospitalized case; the latter provides intensely positive serological results which do not assist the definition of differentiation between positive and negative. The comparison, however, of two serological techniques such as the latex inhibition test of Burby and Behr, and the modified S.C.A.T. of Rose and Waaler, affords a factual numerical assessment, unaffected by clinical doubts and definitions.

While the purport of these results is the factual numerical correlation between the two technical methods, each test must be related to the clinical condition. The severity of the rheumatoid arthritis in the present series varied from the active advanced case with much functional distress to the relatively mild early case. The code of the revised criteria of the committee of the American Rheumatism Association (Ropes, 1959), together with their specified exclusions has provided the guiding principles. The clinical establishment of rheumatoid arthritis required the presence of observed joint swellings with tenderness (dissociated from any evidence of osteo-arthrosis either clinically or radiologically), measured muscle weakness, perspiration of the palms, morning stiffness, and possibly a history of cyclical variations of exacerbations and remissions. Additional evidence was given by the raised erythrocyte sedimentation rate and at times by confirmatory radiological appearances. Differentiation from the degenerative endocrine polyarthritis of the climacteric in females is a more difficult and extensive proposition, to be dealt with in a separate communication.

\section{Methods}

S.C.A.T. - The original method of Rose and others (1948) was employed with two modifications. Preliminary absorption of heterophil agglutinins (Ball, 1950) was used, and the sheep erythrocytes were sensitized by the addition of 5 minimum haemolytic doses of rabbit anti-sheep cell serum (Difco). Agglutination at a dilution of $1: 32$ or more was considered as positive.

Latex Inhibition Test.-Latex suspension was prepared by diluting the commercial preparation in glycine buffer, so that it had a transmission of 35-41 per cent. or an 
optical density $E_{1 \mathrm{~cm}}=0.46-0.39$ with an Ilford filter 608, with a maximum of $690 \mathrm{~m} \mu$. This necessitated a dilution of $1: 1,000$ with the original Polystyrene Company's product, and of $1: 300$ with the present-day product distributed by B.D.H. All the results recorded here were made with the first original product.

$0.05 \mathrm{ml}$. patient's serum is added to a very clear unscratched test tube $3 \times \frac{3}{8}$ in. containing $0.95 \mathrm{ml}$. glycine buffer. Mix and remove $0.5 \mathrm{ml}$. to a second tube containing $0.5 \mathrm{ml}$. glycine buffer, and so on to make four dilutions $1: 20$ to $1: 160$. $0.1 \mathrm{ml}$. Armour's Bovine Fraction II gamma-globulin in a strength of 0.5 per cent. in glycine buffer is added to each tube. $0.5 \mathrm{ml}$. Polystyrene suspension, diluted as above to correct transmission value, is added to each tube. The control tube contains Latex suspension and Bovine globulin only, without any added serum. All tubes are treated for 2 hours in a water bath at $56^{\circ} \mathrm{C}$. The tubes are removed and allowed to stand in rack overnight at room temperature. Results are read after $18 \mathrm{hrs}$, by viewing by transmitted daylight, preferably not in sunlight. Three stages of agglutination are noted:

(i) A change in colour of opacity from a transparent blue tint to less transparent yellowish tint, which if undisturbed by agitation, can be seen as sedimenting with a line of demarcation below the top level of the fluid.

(ii) A greater degree of agglutination, with particles visible through a hand lens and some small sediment at the bottom of the tube.

(iii) A complete agglutination and sedimentation.

Any one of these three types occurring in the 1:20 and $1: \mathbf{4 0}$ dilutions is read as a positive reaction. Complete agglutination usually occurs when the S.C.A.T. reaches a titre of $1: 256$ or higher. The control tube should always show a complete agglutination.

The modern B.D.H. product does not agglutinate in the same way, but, as suggested by Burby and Behr (1959), gives a quite satisfactory reagent, if it is diluted to the correct transmission value and the Bovine gammaglobulin is increased to $0.2 \mathrm{ml}$. per tube. The same inhibitory phenomenon can then be utilized.
Glycine buffer is used as described by Burby an Behr (1958).

More recent experience suggests that these Latex colloidal suspensions may suffer with "ageing", as: a result of which they become quite useless for theses purposes. A control tube of Latex suspensiono diluted first to the correct transmission value and later as in the standard test, heated, and cooled $\bar{s}$. overnight, should show a pale bluish opalescence $\mathbb{\Omega}^{\mathbb{D}}$ only. If it is "aged", then opacity and agglutination may occur.

\section{Results}

Bovine Fraction II globulin by itself causes agglutination of the Latex particles. Table I shows a typical experiment and indicates the quantitative nature of the reaction. From such results, the employment of $0.1 \mathrm{ml} .0 .5$ per cent. solution of Bovine globulin as the optimal amount was derived for a standard test, being the most sensitive position giving no appreciable agglutination with normal serum to the dilution of $1: 80$. 300 consecutiven specimens of sera from ambulant patients (149 with rheumatoid arthritis and 151 with other types of arthritic disease) were determined for their agglutina $\frac{\mathbb{s}}{\text { - }}$ tion capacity by both tests, each of the two tegts being carried out simultaneously by different sectiक्ञा of the laboratory staff. The results were compays after a clinical assessment of the diagnosis had berp obtained. Table II (opposite) gives the genera results.

The non-rheumatoid arthritic group include $\mathscr{g}^{\circ}$ cases of ankylosing spondylitis, rheumatic fever? gout, osteo-arthrosis, non-articular manifestations $\overrightarrow{\bar{Q}}$ and physical or traumatic deformities. The defini tion of a polyarthritis in the female of the climacterie period and during the degenerative period in the. later decades, is becoming recognized as not neces?

TABLE I

LATEX AGGLUTINATION RELATED TO BOVINE F.II AS SENSITIZING AGENT

Results with Latex Suspension (Or:ginal Polystyrene) $0.5 \mathrm{ml}$. with Different Amounts of Bovine F.II 0.5 per cent.

\begin{tabular}{|c|c|c|c|c|c|c|c|c|}
\hline Dilution of Normal Serum & . & $1 / 20$ & $1 / 40$ & $1 / 80$ & $1 / 160$ & $1 / 320$ & $1 / 640$ & $1 / 1,280 D$ \\
\hline Bovine F.II 0.5 per cent. (ml. per tube) & $\begin{array}{l}0 \cdot 2 \\
0 \cdot 1 \\
0 \cdot 05 \\
0 \cdot 025\end{array}$ & $\begin{array}{l}\mathbf{0} \\
\mathbf{0} \\
\mathbf{0} \\
\mathbf{0}\end{array}$ & $\begin{array}{l}\mathbf{0} \\
\mathbf{0} \\
\mathbf{0} \\
\mathbf{0}\end{array}$ & $\begin{array}{l}+ \\
0 \\
0 \\
0\end{array}$ & $\begin{array}{c}++ \\
+ \\
0 \\
0\end{array}$ & $\begin{array}{r}++ \\
+ \\
0\end{array}$ & $\begin{array}{l}++ \\
++ \\
+ \\
+\end{array}$ & $\begin{array}{l}++ \text { 三. } \\
++N \\
++ \text { S } \\
++\end{array}$ \\
\hline
\end{tabular}

Results with Different Types of Latex Suspension $(0.5 \mathrm{ml}$.) with Different Proportions of Glycine Buffer and Bovine F.II

\begin{tabular}{|c|c|c|c|c|c|c|c|c|c|c|c|c|}
\hline \multicolumn{2}{|l|}{$\begin{array}{l}\text { Glycine Buffer (ml.) } \\
\text { Bovine F.II 0.5 per cent. (ml.) }\end{array}$} & $\begin{array}{l}\ldots \\
\cdots\end{array}$ & $\begin{array}{l}\ldots \\
\therefore\end{array}$ & $\begin{array}{l}\cdots \\
\cdots\end{array}$ & $\begin{array}{l}\cdots \\
\cdots\end{array}$ & \multirow{2}{*}{$\begin{array}{c}0.5 \\
0 \\
0 \\
0\end{array}$} & \multirow{2}{*}{$\begin{array}{c}0.45 \\
0.05 \\
+ \\
0\end{array}$} & \multirow{2}{*}{$\begin{array}{l}0.4 \\
0.1 \\
\begin{array}{c}++ \\
+\end{array}\end{array}$} & \multirow{2}{*}{$\begin{array}{r}0.35 \\
0.15 \\
++ \\
++\end{array}$} & \multirow{2}{*}{$\begin{array}{l}0 \cdot 3 \\
0 \cdot 2 \\
++ \\
++\end{array}$} & \multirow{2}{*}{$\begin{array}{l}\begin{array}{l}0.25 \\
0.25\end{array} \\
\begin{array}{l}++ \\
++\end{array}\end{array}$} & \multirow{2}{*}{$\begin{array}{l}\mathbf{0 . 2} \\
\mathbf{0 . 3} \\
++ \\
++\end{array}$} \\
\hline Latex Suspension & $\begin{array}{l}\text { Oris } \\
\text { B.D }\end{array}$ & gina & $\begin{array}{l}\text { lys } \\
\text { see }\end{array}$ & & $\cdots$ & & & & & & & \\
\hline
\end{tabular}

$0=$ No agglutination

$+=$ Partial agglutination

$++=$ Complete agglutination 
TABLE II

SIMULTANEOUS COMPARISON OF 300 CASES WITH THE SHEEP-CELL AGGLUTINATION TEST AND THE LATEX PARTICLE INHIBITION TEST

\begin{tabular}{|c|c|c|c|c|c|c|}
\hline \multirow{3}{*}{ Condition } & \multirow{3}{*}{ No. of Cases } & \multirow{3}{*}{ Result of Test } & \multicolumn{4}{|c|}{ Test } \\
\hline & & & \multicolumn{2}{|c|}{ S.C.A.T. } & \multicolumn{2}{|c|}{ Latex } \\
\hline & & & No. & Per cent. & No. & Per cent. \\
\hline \multirow{2}{*}{ Rheumatoid Arthritis } & \multirow{2}{*}{149} & + & 109 & $73 \cdot 15$ & 105 & $70 \cdot 5$ \\
\hline & & - & 40 & $26 \cdot 85$ & 44 & $29 \cdot 5$ \\
\hline \multirow{2}{*}{ Non-rheumatoid Arthritis } & \multirow{2}{*}{151} & + & 4 & $2 \cdot 7$ & 16 & $10 \cdot 6$ \\
\hline & & - & 147 & $97 \cdot 3$ & 135 & $89 \cdot 4$ \\
\hline
\end{tabular}

sarily homogeneous. This has been suggested by Olsen and Rantz (1958) and by Miall, Ball, and Kellgren (1958). Sex differences of this type were reported earlier by Ball (1952), Jacobson, Kammerer, Wolf, Epstein, and Heller (1956), and Alexander and de Forest (1954). Climacteric degenerative endocrine polyarthritis has been included as nonrheunatoid arthritis where the clinical evidence was sufficient to establish it.

Table III enumerates divergencies in greater detail; the last column shows the figure reported by Steinberg (1959) for 504 cases, in a similar comparison between the S.C.A.T. and the Plotz and Singer technique, using the Dow Latex suspension. His figures have been recalculated to the same total numbers.

\section{Discussion}

There is an apparent close relationship between the results of the two test techniques (83.3 per cent.). The correlation is closer with the Dow latex sus- pension although the British polystyrene latex suspension does not fall far behind. For clinical assessment the S.C.A.T. is slightly more sensitive and accurate, especially in its lower rate of false positives. The nature of this group of clinical cases provides a series of the most difficult types to differentiate both serologically as well as clinically. The latex technique allows a considerable saving in time and labour, and it is possible to get the result in a routine laboratory within 24 hours of the venepuncture. Only the established diagnosis has been taken into account, without considering the effect of treatment or the severity or duration of symptoms. The stability of positive reactions irrespective of rheumatic activity and other features has been recognized, but recent reports suggest that changes may occur as a result of treatment (Michotte, Vanslype, Tritsmans, and Verstraete, 1959; De Forest, Mucci, and Boisvert, 1958) and many of the patients in this series are in fact undergoing active therapy.

TABLE III

DETAILED COMPARISON OF CONVERGENCE AND DIVERGENCE IN SHEEP-CELL AGGLUTINATION TEST AND THE LATEX PARTICLE INHIBITION TEST

\begin{tabular}{|c|c|c|c|c|c|c|c|}
\hline \multirow{2}{*}{ Condition } & \multirow{2}{*}{ No. of Cases } & \multicolumn{2}{|c|}{ Results of Tests } & \multicolumn{2}{|c|}{ Present Series } & \multicolumn{2}{|c|}{ Steinberg } \\
\hline & & S.C.A.T. & Latex & Convergence & Divergence & Convergence & Divergence \\
\hline Rheumatoid Arthritis & 149 & $\begin{array}{l}+ \\
+ \\
-\end{array}$ & $\begin{array}{l}+ \\
\dot{t} \\
-\end{array}$ & $\begin{array}{l}92 \\
27\end{array}$ & $\begin{array}{l}17 \\
13\end{array}$ & $\begin{array}{l}88 \\
47\end{array}$ & $\begin{array}{l}9 \\
6\end{array}$ \\
\hline Total & $\cdots$ & . & $\cdots$ & 119 & 30 & 135 & 15 \\
\hline Non-rheumatoid Arthritis & 151 & $\begin{array}{l}+ \\
+ \\
-\end{array}$ & $\begin{array}{l}+ \\
\dot{+} \\
-\end{array}$ & $\begin{array}{r}0 \\
131\end{array}$ & $\begin{array}{r}4 \\
16\end{array}$ & $\begin{array}{r}2 \\
142\end{array}$ & $\begin{array}{l}3 \\
4\end{array}$ \\
\hline Total & $\cdots$ & . & $\ldots$ & 131 & 20 & 144 & 7 \\
\hline \multirow{2}{*}{ Grand Totals .. } & \multirow{2}{*}{$\cdots$} & \multirow{2}{*}{$\cdots$} & No. .. $\quad \ldots$ & 250 & 50 & 279 & 22 \\
\hline & & & Per cent. $\quad .$. & $83 \cdot 3$ & $16 \cdot 7$ & $92 \cdot 7$ & $7 \cdot 3$ \\
\hline
\end{tabular}


It must be emphasized that these results, in so far as the latex technique is concerned, are derived entirely from the application of the Burby and Behr technique which, with the original British preparation, was found to involve the inhibition by normal sera, and they are not necessarily applicable to other techniques. Greenbury (1958) reported that, in his experience, this form of Latex suspension was inferior to the American (Dow) preparation, but his observations related to the Plotz and Singer technique, which is probably fundamentally different in its chemical reactions and does not necessarily depend upon the inhibitory functions of the normal serum. Burby and Behr (1959) report satisfactory correlative findings. The employment of these relatively simple mixtures affords a means of determining the nature of these reactions in greater detail, and it is hoped to report upon them in the near future.

\section{Summary}

Technical details of a method utilizing British Polystyrene Latex particles in the agglutination test for rheumatoid arthritis described by Burby and Behr $(1958,1959)$ are set out. The results of this test are compared with those of the standard sheep cell agglutination test in $\mathbf{3 0 0}$ simultaneous examinations. The two tests agreed in 83.3 per cent. of results. In assessment with the clinical diagnosis, the sheep cell agglutination test was found to be more sensitive and accurate, mainly because of the smaller number of false positive reactions.

\section{REFERENCES}

Alexander, R., and de Forest, G. K. (1954). Amer. J. Med., 16, 191. Ball, J. (1950). Lancet, 2, 520.

- (1952). Ann. rheum. Dis., 1197.

Burby, G., and Behr, G. (1958). Lancet, 2, 1157.

C. (1959). Ibid., 1, 1209.

Coke, H. (1958). Ibid., 2, 1286. de Forest, G. K., Mucci, M., and Boisvert, P. L. (1958). Arthr. and Rheum., 1, 387

Greenbury, C.' L. (1958). Lancet, 2, 1374.

Jacobson, A. S., Kammerer, W. H. Woif J., Epstein, W. V., and Heller, G. (1956). Amer. J. Med., 20, $490 . \quad$ ( Miall, W. E., Bail, J., and Kellgren, J. H. (1958). Ann. rheum. Dis., $17,263$.

Michotte, L., Vanslype, J., Tritsmans, E., and Verstraete, J. J. (1959). J. belg. Méd. phys. Rhum., 14, 5.

Olsen, C. R., and Rantz, R. A. (1958). Arthr. and Rheum., 1, 54.

Plotz, C. M., and Singer, J. M. (1956). Amer. J. Med., 21, 893.

Ropes, M. W. (1959). Ann. rheum. Dis., 18, 49.

Rose, H. M., Ragan, C., Pearce, E., and Lipman, M. O. (1948) Proc. Soc. exp. Biol. (N.Y.), 68, 1.

Steinberg, V. L. (1959). Lancet, 1, 555.

Waaler, E. (1940). Acta path. microbiol. scand., 17, 172.

Ziff, M. (1957). J. chron. Dis., 5, 644.

Essai de la suspension britannique de Latex pour les:réactions d'agglutination dans l'arthrite rhumatismale $\vec{\omega}$ RÉSUMÉ

On présente les détails techniques d'un procédé employant des particules de Latex, un polystyrène britannique, dans la réaction d'agglutination pour $\infty$ l'arthrite rhumatismale, selon Burby et Behr $(1958,1959) .+$ On compare les résultats de cette réaction à ceux obtenus avec la réaction d'agglutination de globules de moutonstandard en 300 examens simultanés.

Il y eut un accord entre les deux réaction dans $83,3 \%$ 글 des résultats. Par rapport aux procédés chimiques, $\vec{\nabla}$ la réaction d'agglutination de globules de mouton ${ }_{\mathbb{\infty}}$ s'avéra plus sensible et plus précise, surtout en raison d'un nombre plus petit de réactions positives fausses.

Experiencia con suspensión británica de Latex para reacciones de aglutinación en la artritis reumatoideo $\overrightarrow{0}$ Sumario

Se presentan los detalles técnicos de un método usan⿳亠丷厂 partículas de Latex, un polistireno británico, en ła reacción de aglutinación para la artritis reumatoide, según Burby y Behr $(1958,1959)$. Se comparan losō resultados de esta reacción a los obtenidos con la reacción de aglutinación de eritrocitos de carnero standard en $\Phi$ 300 investigaciones simultáneas.

Ambas reacciones se acordaron en un $83 \%$ de los $\overline{\bar{O}}$ resultados. En comparación con los métodos químicos, 3 la reacción de aglutinación de eritrocitos de cordero se mostró más sensible y más precisa, particularmentę por dar menos falsas reacciones positivas. 